\title{
Freedom, democracy and extremism in the Slovak Republic
}

\author{
PhDr. Matúš VYROSTKO
}

\begin{abstract}
The issue of the rise of extremism in the Slovak Republic and other Central European states - especially in Hungary, the Republic of Poland and the Czech Republic, has been intensively discussed especially in recent years. The aim of our contribution is to answer the question of when measures directed against extremism in the Central European diapason focusing on the Slovak Republic are legitimate and when they become a counterproductive "fight". We offer the answer based on an analysis and comparison of the legal order related to extremism and freedom of speech in the Slovak Republic, identification and analysis of measures against extremism in the Slovak Republic and, last but not least, case study in the town of Snina. Is the restriction of the freedom of speech or the restriction of the freedom of assembly a legitimate measure in the fight against extremism in the Slovak Republic? How does Government of the Slovak Republic try to combat extremism?
\end{abstract}

\section{Keywords}

extremism, Central Europe, freedom of speech, freedom of assembly, measures against extremism

\section{Introduction}

It has been a hundred years since the independence of Central European countries known as V4 - Hungary, Republic of Poland, Slovak Republic and Czech Republic. One of the main manifestations of their independence is their sovereignty linked to freedom of decision, which states apply for example, in the case of inadequate reception of migrants under the so-called mandatory quotas. In practice, this means that the states decide who they want to cooperate with, which treaties they want to sign, what international structures or organizations they want to join or leave.

In addition to international relations, freedom is a core social value within states. When are measures against a negative phenomenon such as extremism a legitimate fight against extremism and when such measures limit one of the fundamental expressions of freedom - freedom of speech and freedom of assembly?

In the globalized world, there is no doubt that the expressions of extremism that arise from inspiration, influence and communication between people are mutually similar. Extremism 
thus shows similarities in the V4 countries as well as in other European countries. This fact is confirmed by the strategy document Concept of Combating Extremism for 2011-2014, according to which extremism in the Slovak Republic ("hereinafter: SR") is heavily influenced by extremism in the surrounding states, especially in the Czech Republic, the Republic of Poland, the Federal Republic of Germany, Hungary and Republic of Serbia. A contiguous phenomenon, according to the strategic document Concept of Combating Extremism for 2011-2014 (Resolution of the Government of the Slovak Republic No. 379 of 8 June 2011), is increasing serious crime and intolerant attitudes of certain groups of the population towards certain minority groups, especially those belonging to the Romani ethnic group and aliens. ${ }^{1}$

As we mention in the contribution below in the part where we analyze the definition of extremism, it should be emphasized that since it is possible to distinguish between different types of extremism, the measures against extremism will naturally differ. For the purpose of this contribution, we focus in particular on "universal" measures, respectively measures aimed at right-wing extremism.

\section{Why are there manifestations and acts associated with extremism in Central Europe in 2018?}

The rise of extremism is a problem that has come to the attention of the broad professional and lay public in the Slovak Republic, especially in recent years. Because we also deal with irregular migration in our scientific work, we believe that it is first and foremost possible to look for a connection with so-called migration crisis, when a large number of irregular migrants arrive in the European Union. Although this fact is used by certain political parties for political marketing purposes, we believe that this is not the main reason for the rise of extremism in the Slovak Republic. There are at least two reasons why we can say so. In our opinion, one of the reasons why migration crisis in the European Union is not the main reason for the increase in extremism, is the number of crimes of extremism in the years 2013-2017. If the migration crisis was the main reason for the increase of extremism in the Slovak Republic, we suppose it would have resulted in a higher number of crimes associated with extremism in recent years, which is not true according to Table 1. As the second reason, we agree with the argument of Slovak expert on extremism Daniel Milo, according to which the rise of extremism can be perceived in the Slovak Republic from 2008 to 2009 when extremists began to change their image, rhetoric, way of expression or themes to obtain greater public support. ${ }^{2}$ Therefore, we think that the reason for the rise of extremism can be found in several factors.

1 Uznesenie vlády Slovenskej republiky č. 379 z 8. júna 2011. Koncepcia boja proti extrémizmu na roky 20112014, online: http://www.rokovania.sk/File.aspx/ViewDocumentHtml/Uznesenie-11819?listName=Uznesenia\&prefixFile=m_ (Downloaded 20 May 2018).

2 BALÁŽOVÁ, Daniela: Milo: Problém extrémizmu nevyrieši len zákon, online: https://spravy.pravda.sk/domace/ clanok/387550-milo-problem-extremizmu-nevyriesi-len-zakon/ (Downloaded 2 April 2018). 
Table 1 Number of crimes of extremism detected in the Slovak Republic in 2013-2017

\begin{tabular}{|c|c|c|c|c|c|}
\hline Year & $\mathbf{2 0 1 3}$ & $\mathbf{2 0 1 4}$ & $\mathbf{2 0 1 5}$ & $\mathbf{2 0 1 6}$ & $\mathbf{2 0 1 7}$ \\
\hline $\begin{array}{l}\text { Number of detected crimes of extremism } \\
\text { in the Slovak Republic }\end{array}$ & 78 & 66 & 30 & 58 & 145 \\
\hline
\end{tabular}

Source: Customized according to: Ministry of Interior of the Slovak Republic. Criminal Statistics in the Slovak Republic for the years 2013, 2014, 2015, 2016, 2017

We believe that another reason why it is possible to monitor the increase in expressions and actions associated with extremism is the success of political parties whose representatives and adherents justify such actions and mitigate their gravity for society or even openly support them. We believe that such statements by representatives of political parties can encourage potential extremists to behave like this. In this context, some proposed solutions to the issue of the migration crisis in the EU, which may appear to be radical or populist, do not seem to contribute to limiting the rise in extremism.

Last but not least, it is possible to say that the problems in society, which may appear to be inadequately and unsuccessfully solved, might contribute to the radicalization of the population and the increase in extremism. We believe some of these problems could be Roma integration, poverty, or poor quality education and health care.

In the Slovak Republic, in the last years, the issue of audience violence has been perceived as a central issue in the context of extremism, as evidenced by the existence of the Department of Extremism and Audience Violence of the Criminal Police Office of the Presidium of the Police Corps. In 2017, however, it is possible to talk about the increased interest of the government of the Slovak Republic in the fight against extremism.

The result of this effort is an amendment to the Criminal Code, as well as the beginning of the operation of the National Unit for Combating Terrorism and Extremism (Office of the Government of the Slovak Republic 2017). ${ }^{3}$

The discussion of the professional and lay public in the Slovak Republic as well as in other countries in Central Europe has intensified the mentioned electoral success of such political parties that can legitimately be considered extremist. In the Slovak Republic, this is especially the political party "Kotleba - Ludová strana Naše Slovensko" ("The People's Party Our Slovakia", hereinafter: "LSNS").

In Hungary, according to Dariusz Kalan, an expert on Central Europe from the Polish Institute of International Affairs, it is especially "Jobbik", as a movement that has strong anti-European, anti-Semitic and anti-Romani statements. ${ }^{4}$ In this case, however, it is necessary to add, as stated by several experts who are concerned with current political developments in Hungary, that in the 2018 parliamentary elections, the Jobbik party shifted from the radical-right position to the center, which even by political scientists, was one of the main reasons for "Weak" electoral results. At the moment, it is questionable whether the party can still be considered as extremist.

3 Na Slovensku začína pôsobit' Národná jednotka boja proti terorizmu a extrémizmu, online: http://www.vlada. gov.sk/na-slovensku-zacina-posobit-narodna-jednotka-boja-proti-terorizmu-a-extremizmu/ (Downloaded 13 August 2018).

4 MATIŠÁK, Andrej: Mad'arskí extrémisti sú skutočná hrozba, nie papierový tiger, online: https://spravy.pravda. sk/svet/clanok/314189-madarski-extremisti-su-skutocna-hrozba-nie- papierovy-tiger/ (Downloaded 20 July 2018 ). 
Mesežňikov complements another political party known as "Úsvit přímé demokracie Tomia Okamury" ("Direct Democracy Dawn in the Czech Republic - Tomio Okamura"), as a extremist threat, and also the right-wing extremist party "DSSS" and the "Nechceme Islám v České republice" ("We Do not Want Islam Movement in the Czech Republic") and the ultra-nationalist "Liga Polskich Rodzin" ("League of Polish Families") in the Republic of Poland as an extremist threat in Central Europe. ${ }^{5}$

Based on the above information, there is a question as to what measures states should use against extremism and whether such measures are legitimate and legal.

\section{Theoretical background - How can we define extremism?}

Even before specific proposals to combat extremism, it is necessary to define it. In the Slovak Republic, extremism is not defined in the legal order of the Slovak Republic, leaving room for its interpretation in practice. How different authors understand extremism has a direct impact on what measures should be used against extremism. This is all the more complicated, we can claim almost impossible, to define extremism in Central Europe or even in the European Union.

The complexity of defining extremism naturally results either in the refusal to create a definition associated with the view of the impossibility of such a universal definition, the attempt to create it, or the identification of an existing definition of extremism. In our case, we are particularly inclined to the last alternative.

In the diapason of the Slovak republic, the extensive definition of the Ministry of Interior of the Slovak republic, which is also used by the Government of the Slovak republic in the Concept of Combating Extremism for the years 2015-2019, appears to us as adequate. "Extremism denotes acts and manifestations based on attitudes of the extremist, hostile ideology to the democratic system which, either directly or at a certain time horizon, are destructively affecting the existing democratic system and its basic attributes. The second characteristic feature of extremism and its associated activities is that they attack the system of fundamental rights and freedoms guaranteed by the Constitution and international human rights documents or seek to make their exercise more difficult or impossible by their activities. The other characteristics of extremism are the attempt to restrict, suppress, impede the exercise of fundamental rights and freedoms for certain groups of the population defined by their gender, nationality, race, ethnicity, skin color, religion, language, sexual orientation, belonging to the social class, as well as the use of physical violence or the threat of using violence directed against opinion or political opponents or their property..." (Resolution of the Government of the Slovak Republic No. 129 of 18 March 2015, p. 3). ${ }^{6}$

The Ministry of Interior of the Slovak Republic also points out the types of extremism and states, that extremism is divided into right-wing, left-wing, religious and extremism focused on one question.

5 MESEŽNIKOV, Grigorij: Pravicový extrémizmus v strednej Európe: Nacionalistická politika, utečenecká kríza a výzvy pre demokratov, online: http://www.ivo.sk/buxus/docs/publicistika/subor/Mesez_Boell_23_10_15.pdf (Downloaded 12 August 2018).

6 Uznesenie vlády Slovenskej republiky č. 129 z 18. marca 2015. Koncepcia boja proti extrémizmu na roky 20152019 , p. 3, online: http://www.rokovania.sk/File.aspx/ViewDocumentHtml/Uznesenie-14720?listName=Uznesenia\&prefixFile=m_ (Downloaded 15 June 2018). 
Although the understanding and definition of extremism is not the essence of our contribution, fighting the rise of extremism, effective measures against extremism, and conflicts with constitutionally guaranteed freedom of expression can not be said without clearly identifying what actions and manifestations we consider to be extremist. In the context of the perception of extremism, it is therefore necessary to emphasize that extremism can be understood in several forms.

There may be at least 3 forms of understanding extremism. The first form is extremism as a criminal activity. According to this understanding, only those acts, that are classified as a criminal offense under the Criminal Code, can be called extremists. The second form is the understanding of extremism as actions and manifestations that are not universally recognized and accepted in a democratic society. The third is the understanding of extremism as any behavior or manifestations that do not correspond to the views of the functioning of society and the state that a person, who understands extremism as such, considers as universally and absolutely correct. ${ }^{7}$

As stated by sociologist Zora Bútorová, on the basis of her research it is possible to pronounce a sentence: "Tell me who you vote for in the elections and I will tell you how you understand extremism. In this way, it would be possible to summarize the findings on the influence of political preferences on the perception of extremism. ${ }^{\prime \prime}$

In addition to the above considerations, it should be emphasized that since it is possible to distinguish between different types of extremism, the measures against extremism will naturally differ. For the purpose of this contribution, we focus in particular on "universal" measures, respectively measures aimed at right-wing extremism.

Regarding the issue of defining extremism, it would naturally be possible to talk about other important aspects, for example the determination of the boundary between radicalism and extremism, or the clear definition of other terms, such as nationalism or fascism. Since however, such a comparison would exceed the possibilities of this contribution, with regard to the subject of this contribution, we are dealing with measures against extremism in the Slovak Republic in the next part.

We believe that there is one important fact that needs to be mentioned. In order to be able to combat the negative social phenomena in a democracy, including extremist actions and expressions, it is essential for the democratic system to be able, along with the guarantee of fundamental rights, to legitimately limit them as well. This is the principle of so-called "Defensive Democracy". The practical outcome is a legal guarantee of fundamental rights, which can be limited in legitimate cases, as is the case with the Slovak Republic.

One possible manifestation of the application of "Defensive Democracy" is the restriction of political parties that can threaten the democratic system. As Navot points out in this regard, after the Second World War, one of the main aims was to restrict Nazi and Fascist political parties, while at the present time limiting political parties is also extended to radical or religious political parties. ${ }^{9}$

7 VYROSTKO, Matúš: Extrémizmus v právnom poriadku Slovenskej republiky, in: Zborník príspevkov z 5. ročníka Jarnej internacionalizovanej školy doktorandov UPJŠ 2018, Košice 2018, 245-250.

8 BÚTOROVÁ, Zora: Extrémizmus? Čo to vlastne je?, online: https://dennikn.sk/868358/extremizmus-co-tovlastne-je/ (Downloaded 17 March 2018).

9 NAVOT, Suzie: Fighting Terrorism in the Political Arena: The Banning of Political Parties, in: Party Politics, 14, 


\section{Legal tools to eliminate extremism in the Slovak Republic}

In this context, it should be noted that the Slovak Republic, as a Member State of the European Union, respects the legal regulation of extremism at international and European level. The legal treatment of extremism at international level consists of, for example, The International Convention on the Elimination of All Forms of Racial Discrimination and at European level, The Convention for the Protection of Human Rights and Fundamental Freedoms or Council Framework Decision 2008/913 / JHA of 28 November 2008 on combating certain forms and expressions of racism and xenophobia by means of criminal law. We believe that measures against extremism can be divided into preventive and repressive. Extremism can only be solved by a set of premeditated and follow-up measures that have a legal basis and do not restrict the freedom of persons with illegitimate reason and in an illegitimate manner.

One of the basic measures are the legal tools to eliminate extremism, which is mostly criminal sanction of criminal offenses related to extremism. In the Slovak Republic these are classified as criminal offenses in Act no. 300/2005 Coll. Criminal Code as amended (hereinafter: "Criminal Code"). These include, for example, the production, dissemination and preservation of extremist materials, or incitement to national, racial and ethnic hatred. The crimes of extremism are precisely defined in $\S 140$ a of the Criminal Code. ${ }^{10}$

According to Zachar and Zacharová, the model of the continental legal system was respected in the Slovak Republic in the drafting of the Criminal Code. Progressive criminal-law institutes from the whole period of the first Czechoslovak Republic, from 1948 to 1989 and from 1990 to 1996, were accepted. "The new codification removes from criminal law all the elements that have been subject to the ideological and political postulate of the totalitarian period of our state's development. "11

In 2016 a number of changes have been made in the area of criminal offenses of extremism, with both a general and a specific part of the Criminal Code being changed. According to Škrovánková, the amendment has reworded many facts about the crimes of extremism. ${ }^{12}$ In the SR, minor acts and acts associated with extremism are qualified as offenses. These are, for example, the use of written, pictorial, audio, or audiovisual versions of texts in the public, which are aimed at suppressing fundamental human rights and freedoms. For such an offense, the offender faces a fine of up to 500 euros. ${ }^{13}$ According to several authors, the $\mathrm{SR}$ is the only country in the V4 countries to qualify offenses of extremism.

In the case of the classification of offenses as a criminal offense or offense, it is possible to speak of the preventive and repressive nature of this measure, given that it aims to sanction socially undesirable behavior and discourage potential perpetrators from such actions and manifestations.

$2008,6,745-762$.

10 Zákon č. 300/2005 Z. z., Trestný zákon v znení neskorších predpisov.

11 ZACHAR, Andrej-ZACHAROVÁ, Elena: Čo s problémom pravicového extrémizmu na Slovensku?, in: Justičná Revue, 57, 2005, 11, 1347-1363.

12 ŠKROVÁNKOVÁ, Monika: Novelizácia Trestného zákona a Trestného poriadku so zretel'om na extrémizmus, in: Justičná Revue, 69, 2017, 5, 638-648.

13 Zákon č. 372/1990 Zb., o priestupkoch v znení neskorších predpisov. 
Sanctioning is not and can not be the only measure against extremism. This statement relates to the very understanding of extremism. Not all actions and acts that can be described as extremist are qualified as a crime or an offense, and their social significance is lower. However, this fact should not lead to ignoring such behaviors, but, on the contrary, trying to minimize such behavior by effective preventive measures.

\section{Other measures against extremism in the Slovak Republic}

Although criminal sanction and the classification of acts and events as an offense is a major measure against extremism, we believe that further preventive and follow-up are needed to effectively combat extremism. The conceptual document in the SR is in this context the Concept of Combating Extremism for the Years 2015-2019 in which the Government of the Slovak republic defined four main strategic goals of the concept. It is about:

- strengthening the resilience of communities and individuals against undemocratic ideologies and extremism,

- raising awareness of the manifestations and social significance of extremism and the consequences of radicalization,

- effective monitoring and detection of crimes committed by extremism, prosecution of offenders,

- establishment of institutional and personnel capacities for state bodies performing their role in the protection of constitutional regulation, internal order and state security (Resolution of the Government of the Slovak Republic No. 129 of 18 March 2015). ${ }^{14}$

At present, projects involving various actors seeking to eliminate extremism include, for example, the Teach for Slovakia project, the activities of the International Organization for Migration, the challenge against extremism of the President of the Slovak Republic Andrej Kiska, or various public debates, discussions and information campaigns. One solution could be to rethink the number of lessons students spend on the history of $20^{\text {th }}$ century, because it currently appears as inadequate.

\section{Extremism and restriction of freedom of speech and freedom of assembly in the legal order of the Slovak Republic}

One of the most frequent arguments of persons who may be defined as extremists by the definition of the Ministry of Interior of the Slovak republic is the restriction of the freedom of speech in the case of their public speeches or proceedings. The question arises when there is a limitation, respectively the banning of acts and expressions by legitimate measures against extremism, and when it is an unjustified restriction of freedom of speech. We think that the answer to this question will be different in any particular case of prohibition or limitation of the expression or encounter of persons associated with extremism.

First of all, as we already mentioned above, before analysing the legal regulation of this issue in the legal order of the Slovak Republic, it must be said that the Slovak Republic,

14 Uznesenie vlády Slovenskej republiky č. 129 z 18. marca $2015 \ldots$ 
as a Member State of the European Union, respects the international and European legislation related to the freedom of speech and the freedom of assembly and association. In particular, the Convention for the Protection of Human Rights and Fundamental Freedoms as amended by later Protocols, signed at the level of the Council of Europe (European Convention on Human Rights, hereinafter: "Convention"), is particularly important in this context, where the Slovak Republic, as a member of the Council of Europe, is a contracting party to the Convention, which means that it is bound by this Convention. The commitment of the Slovak Republic highlights and supplements art. 7 sec. 5 of the Constitution of the Slovak Republic (No. 460/1992 Coll., as amended), (hereinafter: "Constitution of the SR"), according to which "International treaties on human rights and fundamental freedoms, international treaties in which the law does not require implementation, and international treaties which directly establish the rights or obligations of natural persons or legal persons and which have been ratified and proclaimed in the manner prescribed by law, take precedence over the law." The interest in protecting freedom of expression and freedom of assembly and association is expressed in art. 10 and art. 11 of the Convention, and the Convention does not forget to include cases of a legitimate restriction of those freedoms. According to art. $10 \mathrm{sec}$. 2 "The exercise of these freedoms, since it carries with it duties and responsibilities, may be subject to such formalities, conditions, restrictions or penalties as are prescribed by law and are necessary in a democratic society...". Similarly, art. $11 \mathrm{sec} .2$ of the Convention states, that "No restrictions shall be placed on the exercise of these rights other than such as are prescribed by law and are necessary in a democratic society". ${ }^{15}$ In the case of suspected violations of their fundamental rights, people can therefore turn to the European Court of Human Rights (ECHR), which also applies to violations of freedom of expression and freedom of assembly and association. Judgments on the breach of rights are binding for the countries concerned. The Committee of Ministers of the Council of Europe subsequently monitor the execution of such judgments.

Freedom of speech is legally anchored in art. 26 of the Constitution of the SR. According to art. $26 \mathrm{sec}$. 1 of the Constitution of the SR, the freedom of expression and the right to information are guaranteed. According to art. $26 \mathrm{sec}$. 2 of the Constitution of the SR, everyone has the right to express their opinions in words, in print, in pictures or in other ways and according to sec. 3 of the same article of the Constitution of the SR, censorship is prohibited. This very argument is often used by representatives and adherents of those movements, that can be described as extremist. Purposely, however, they do not mention the art. $26 \mathrm{sec}$. 4 of the Constitution of the SR, according to which the freedom of expression and the right to search for and disseminate information may be restricted by law in the case of measures in a democratic society necessary for the protection of the rights and freedoms of others, state security, public order, protection of public health and morality. Thus, the area of legal restriction of freedom of expression exists and is legitimate to use it in those cases where such acts endanger the rights and freedoms of others, state security, public order, protection of public health and morality. ${ }^{16}$

15 Oznámenie Federálneho ministerstva zahraničných vecí č. 209/1992 Zb., o Dohovore o ochrane ludských práv a základných slobôd, online: https://www.noveaspi.sk/products/lawText/1/39918/1/2 (Downloaded 15 January 2019).

16 Ústavný zákon č. 460/1992 Zb., Ústava Slovenskej republiky v znení neskorších predpisov. 
Such cases include, for example, cases in which a person is responsible for the offense of denial and approval of the Holocaust, crimes of political regimes and crimes against humanity under $\S 422 d$ of Act no. 300/2005 Coll. Criminal Code as amended. Limiting the freedom of speech and the consequent sanction is completely legal in this case and, let us argue, even legitimate, but that can be the subject of discussion. ${ }^{17}$

\section{Conflict of freedom of speech and assembly with extremist ex- pressions and actions based on a case in the town of Snina}

The freedom of speech is closely related to the freedom of assembly and association, which are also anchored in the Constitution of the SR. In this context, one of the current controversial cases, which leaves room for discussion, is the case of the Mayor of town Snina, who banned the public assembly of representatives and supporters of the political party L'SNS.

As the official purpose of the L'SNS assembly, they said they wanted to point out a high increase in criminality of inappropriate citizens, and to demand increased police force work in risky and problematic locations in Snina county. ${ }^{18}$

The town of Snina in the Decree on the prohibition of the assembly no. 01/2018/ZH/Pr prohibits the organization of a public assembly. Right from the beginning, it states that the purpose of the assembly is not in direct or literal contradiction with the provisions of $\S 10$ sec. (1) a) of Act no. 84/1990 Coll. on the assembly right as amended, but in relation to other facts. As other facts, the document indicates suspicion that the L'SNS is an extremist political party on the basis of an initiative to cancel the L'SNS filled by the Prosecutor General of the Slovak Republic, Jaromír Čižnár, the ongoing prosecution against NRSR deputy Milan Mazurek or the reason that there is no increased crime in the town of Snina. ${ }^{19}$

In this case, however, we have seen a paradoxical, we assume an unlawful too, ban on the assembly of representatives and supporters of L'SNS. The Government of the Slovak Republic itself in the Concept of Combating Extremism for 2011-2014 (Resolution of the Government of the Slovak Republic No. 379 of 8 June 2011) states in point 1, the value framework of the concept, that the important rights guaranteed by the Constitution of the SR includes freedom of assembly and the right to association. ${ }^{20}$ According to art. 28 sec. 1 of the Constitution of the SR, the right to peaceful assemble is guaranteed. According to Art. $28 \mathrm{sec}$. 2 of the Constitution of the SR, the conditions for the exercise of this right shall be laid down by law in cases of gathering in public places in the case of measures in a democratic society necessary for the protection of the rights and freedoms of others, the protection of public order, health and morals, property or state security. The Constitution

17 Zákon č. 300/2005 Z. z., Trestný zákon v znení neskorších predpisov.

18 ŠNíDL, Vladimír: Primátor Sniny zakázal kotlebovcom míting proti Rómom. Oprel sa o dôvody, ktoré zákon nepozná, online: https://dennikn.sk/1205044/primator-sniny-zakazal-kotlebovcom-miting-proti-romom-oprel-sao-dovody-ktore-zakon-nepozna/ (Downloaded 15 August 2018).

19 Rozhodnutie o zákaze zhromaždenia č. 01/2018/ZH/Pr, online: https://www.snina.sk/e_download.php?file=data\%2Furedni_deska\%2Fobsah559_14.pdf\&original=Rozhodnutie\%20o\%20zákaze\%20zhromaždenia\%20č\%20 \%20\%201-\%202018.pdf (Downloaded 14 August 2018).

20 Uznesenie vlády Slovenskej republiky č. 379 z 8 . júna $2011 \ldots$ 
also states that the assembly must not be subject to authorization by the public administration. ${ }^{21}$ Other aspects of banning the assembly are set out in Act no. 84/1990 Coll. on the assembly right as amended (hereinafter: the "Act on the assembly right"). According to $\S 10 \mathrm{sec}$. 1 of the Act on the assembly right, the municipality notified by the assembly would disqualify it if the stated purpose of the assembly were to appeal to:

- deny or restrict the personal, political or other rights of citizens for their nationality, sex, race, origin, political or other thought, religion and social status, or to incite hatred and intolerance for these reasons, or,

- committing violence or gross indecency or,

- otherwise violate the Constitution, constitutional laws, laws and international treaties to which is the Slovak Republic bound and which take precedence over the laws of the Slovak Republic. ${ }^{22}$

The municipality would ban the assembly, further under $\S 10 \mathrm{sec} .2$ of the Act on the assembly right, even if the assembly were:

- to be held at a place where the participants would be in serious danger to their health or,

- in the same place and at the same time, a meeting should be held according to a previously served notice, and there was no agreement between the conveners to adjust the time of its proceedings; if it is not possible to determine which notification was received earlier, it shall decide with the participation of the representatives of the appellants by drawing, or,

- to be held in the same place and at the same time as a public cultural or sport event has already been authorized under current legislation. ${ }^{23}$

In addition, the municipality may, according to $\S 10 \mathrm{sec}$. 3 of the Act on the assembly right, prohibit a meeting if it would take place in a space where the constraint of traffic and supply would be in serious conflict with the interest of the population, if it is possible, without inadequate difficulty, to hold the assembly elsewhere without compromising the stated purpose of the assembly. According to $\S 10 \mathrm{sec}$. 4 of the Act on the assembly right, the municipality cannot ban the assembly for the reasons given in section 2 and 3 if the convener has accepted a municipal proposal pursuant to $\S 8$ (proposal to hold the meeting in another place). ${ }^{24}$

Therefore, the municipality has to consider only the notified purpose of the assembly and the place where the assembly is to be held. In this case, the legal requirements for banning the assembly from the town of Snina were not met.

It is therefore possible to say that such a decision by the town of Snina did not have the legal basis and the notifiers of the assembly, the party of the L'SNS and its adherents, rather supported the decision to come to the assembly and take advantage of the city's decision in favour of gaining further adherents. The assembly, despite the ban, had taken place.

21 Ústavný zákon č. 460/1992 Zb., Ústava Slovenskej republiky v znení neskorších predpisov.

22 Zákon č. 84/1990 Zb., o zhromažd'ovacom práve v znení neskorších predpisov.

23 lbidem.

24 lbidem. 
Let us therefore argue, that this is not an effective form of fighting against extremism and, on the basis of the above case, we propose to start a discussion about the amendment to the Act on the assembly right. However, we think that the proposals to amend the law on the assembly, the content of which would be to tighten the conditions under which citizens can assemble, would not meet with great support and understanding. A similar situation occurred in 2017 in the Republic of Poland and in 2018 in Hungary. Despite criticism, the two laws finally got enough support in both countries and became part of the legal order.

\section{Conclusion}

Based on an analysis of the law and the case study of town Snina, we have come to the conclusion, that if a democratic society is interested in fighting extremism legally and legitimately, it is very important to stick to the law and not to deviate from the limits of the law. Otherwise, restrictions of freedom of speech and freedom of assembly as well as other measures against extremism can be considered counterproductive, which unnecessarily contributes to further hatred and motivation to act in order to "fight" against the "unlawful" democratic system.

Last but not least, it must be stressed that democracy can not, in its essence, completely eliminate extremism, it can only be effectively reduced by a set of premeditated and follow-up measures in the form of legal tools and other preventive measures.

\section{References}

BALÁŽOVÁ, Daniela: Milo: Problém extrémizmu nevyrieši len zákon, online: https://spravy. pravda.sk/domace/clanok/387550-milo-problem-extremizmu-nevyriesi-len-zakon/ (Downloaded 2 April 2018).

BÚTOROVÁ, Zora: Extrémizmus? Čo to vlastne je?, online: https://dennikn.sk/868358/ extremizmus-co-to-vlastne-je/ (Downloaded 17 March 2018).

MATIŠÁK, Andrej: Mad'arskí extrémisti sú skutočná hrozba, nie papierový tiger, online: https://spravy.pravda.sk/svet/clanok/314189-madarski-extremisti-su-skutocna-hrozba-nie- papierovy-tiger/ (Downloaded 20 July 2018).

MESEŽNIKOV, Grigorij: Pravicový extrémizmus v strednej Európe: Nacionalistická politika, utečenecká kríza a výzvy pre demokratov, online: http://www.ivo.sk/buxus/docs/publicistika/subor/Mesez_Boell_23_10_15.pdf (Downloaded 12 August 2018).

NAVOT, Suzie: Fighting Terrorism in the Political Arena: The Banning of Political Parties, in: Party Politics, 14, 2008, 6, 745-762.

Na Slovensku začína pôsobit' Národná jednotka boja proti terorizmu a extrémizmu, online: http://www.vlada.gov.sk/na-slovensku-zacina-posobit-narodna-jednotka-boja-proti-terorizmu-a-extremizmu/ (Downloaded 13 August 2018).

Oznámenie Federálneho ministerstva zahraničných vecí č. 209/1992 Zb., o Dohovore o ochrane l'udských práv a základných slobôd, online: https://www.noveaspi.sk/products/ lawText/1/39918/1/2 (Downloaded 15 January 2019).

Rozhodnutie o zákaze zhromaždenia č. 01/2018/ZH/Pr, online: https://www.snina.sk/e_ download.php?file=data\%2Furedni_deska\%2Fobsah559_14.pdf\&original=Rozhodnutie\%20o\%20zákaze\%20zhromaždenia\%20č\%20\%20\%201-\%202018.pdf (Downloaded 14 August 2018). 
ŠKROVÁNKOVÁ, Monika: Novelizácia Trestného zákona a Trestného poriadku so zretel'om na extrémizmus, in: Justičná Revue, 69, 2017, 5, 638-648.

ŠNÍDL, Vladimír: Primátor Sniny zakázal kotlebovcom míting proti Rómom. Oprel sa o dôvody, ktoré zákon nepozná, online: https://dennikn.sk/1205044/primator-sniny-zakazal-kotlebovcom-miting-proti-romom-oprel-sa-o-dovody-ktore-zakon-nepozna/ (Downloaded 15 August 2018).

Ústavný zákon č. 460/1992 Zb., Ústava Slovenskej republiky v znení neskorších predpisov. Uznesenie vlády Slovenskej republiky č. 129 z 18. marca 2015. Koncepcia boja proti extrémizmu na roky 2015-2019, online: http://www.rokovania.sk/File.aspx/ViewDocumentHtml/Uznesenie-14720?listName=Uznesenia\&prefixFile=m_ (Downloaded 15 June 2018).

Uznesenie vlády Slovenskej republiky č. 379 z 8. júna 2011. Koncepcia boja proti extrémizmu na roky 2011-2014, online: http://www.rokovania.sk/File.aspx/ViewDocumentHtml/Uznesenie-11819?listName=Uznesenia\&prefixFile=m_ (Downloaded 20 May 2018).

VYROSTKO, Matúš: Extrémizmus v právnom poriadku Slovenskej republiky, in: Zborník príspevkov z 5. ročníka Jarnej internacionalizovanej školy doktorandov UPJŠ 2018, Košice 2018, 245-250.

ZACHAR, Andrej - ZACHAROVÁ, Elena: Čo s problémom pravicového extrémizmu na Slovensku?, in: Justičná Revue, 57, 2005, 11, 1347-1363.

Zákon č. 372/1990 Zb., o priestupkoch v znení neskorších predpisov.

Zákon č. 84/1990 Zb., o zhromažd'ovacom práve v znení neskorších predpisov.

Zákon č. 300/2005 Z. z., Trestný zákon v znení neskorších predpisov.

\section{Author}

PhDr. Matúš Vyrostko

Katedra verejnoprávnych disciplín, Fakulta verejnej správy, Univerzita Pavla Jozefa Šafárika v Košiciach

Department of Public Law Disciplines, Faculty of Public Administration, Pavol Jozef Šafárik University in Košice

Popradská 66, 04011 Košice, Slovak Republic

matus.vyrostko@student.upjs.sk 